\title{
OBJECTIVE AND SUBJECTIVE EVALUATION OF THE PHYSICAL RISK FACTORS NEAR A CONVEYOR SYSTEM
}

\author{
Miriama Piňosová', Miriam Andrejiová2, Pavol Liptai ${ }^{1}$, Ervin Lumnitzer ${ }^{1}$ \\ 1 Technical University of Kosice, Department of Process and Environmental Engineering, Letna 9, 04200 Kosice, \\ Slovak Republic, e-mail: miriama.pinosova@tuke.sk, pavol.liptai@tuke.sk, Ervin.lumnitzer@tuke.sk \\ 2 Technical University of Kosice, Department of Applied Mathematics and Informatics, Letna 9, 04200 Kosice, \\ Slovak Republic, e-mail: miriam.andrejiova@tuke.sk
}

Received: 2018.05.15

Accepted: 2018.08.01

Published: 2018.09.01

\begin{abstract}
Currently, emphasis is still placed on risk evaluations of physical factors in workplaces. The aim of this paper was to evaluate objectively and subjectively the noise parameters and microclimate conditions near conveyor systems at the workplace for the handling and sorting postal items. Objective noise measurements were performed using the Norsonic 140 sound analyser, Class 1 and microclimatic conditions using the Testo 435 instrument. The subjective evaluation was performed by the questionnaire method (120; F: 66; M: 54). The result of the research was the assessment of health risks, depending on the sources of noise caused by conveyor systems.
\end{abstract}

Keywords: noise, risk evaluations, workplaces, conveyor systems.

\section{INTRODUCTION}

Conveyor transport is a continuous transport system of the future, which is characterized by high productivity, economic efficiency and ecological harmlessness with minimal impact on the environment in transporting different types of material and under different conditions of use $[1 \div 3]$.

The use of belt conveyor systems is currently widespread. In the past, they were used mainly in mining and processing of mineral raw materials. Nowadays, we also find belt conveyors in automated facilities, production lines, post offices, airports and shops. Each type of workplace requires a specific approach. Each of these con-

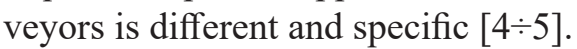

According to Taraba [4], it is important to conduct a diagnosis of the operation of belt conveyors in order to ensure not only their satisfactory technical condition, but also the protection of health of belt conveyor operators against adverse effects (dust, noise, vibrations and poor visibil- ity). Diagnostics makes belt conveyors more reliable and economically less demanding.

A large number of authors $[6 \div 8]$ have evaluated the quality of the work environment and assessed the negative impacts of physical factors in the working environment on the health of employees. Seňová [9] used a points-based assessment method to assess the risk of labouring professions in the quarries. Hnilica [10] focused his attention on the selection of methods that would enable a comprehensive assessment of the impact of risk factors on the working environment of humans. Similarly to Seňová, Hnilica also points out the possibility of using a points system for assessing risk factors in the work environment. As a further option, he chose the questionnaire method, which is a subjective assessment method. Hrušková [11] states that not enough attention is paid to problematic hearing damage from noise in the automotive industry. She warned of the necessity to perform pre-entry medical examinations before people begin work, with appropriate documentation of the exposure to risk factors in past work. Hnilica [12] tries to out- 


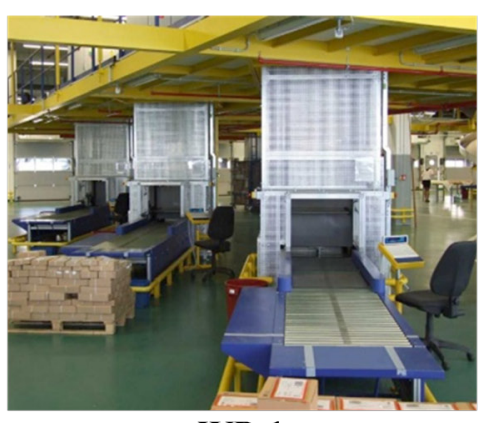

WP-1

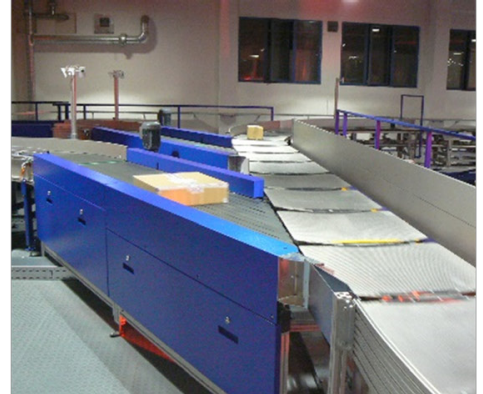

WP-2

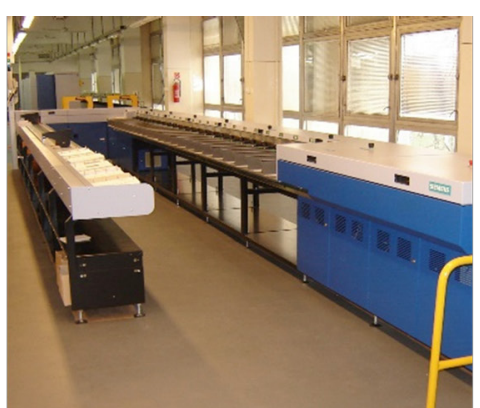

WP-3

Fig. 1. Workplace organization for processing letters and parcels

line the possibility of using multi-criteria decisionmaking methods in the comprehensive assessment of the quality of the working environment in terms of the risk of work. The case study focused on four risk factors (noise, temperature, vibration and psychological load) that have the most significant impact on the health of operators in forestry operations. For the evaluation of these physical factors he chose Saaty's method (analytical hierarchical process). Kapustová [13], using mathematical statistical methods, developed an original mathematical model that enables the expression of the summary effect of negative environmental factors and to evaluate the complex load of the human body during the study period. Tolvanen [14] worked on the measurement of factors in the working environment and the assessment of working conditions at different workplaces. Repeated measurements were made at four locations within the production hall (near the conveyor belt, crusher, tank and barrier). In addition to noise levels, they detected dust concentrations in the air. The authors of this paper have also long been involved in the assessment of the quality of the working environment, and the results of their long-term work were published in 2013 in a monograph entitled "Methodology of Comprehensive Evaluation of Health Risks in Industry II" [15].

\section{MATERIAL AND METHODS}

As a part of the conducted research (subjective and objective evaluation) in the organization processing parcels and letters, we focused on the evaluation of two physical factors (noise and thermal humidity microclimates) in three workplaces, Fig. 1:

- Workplace 1 (WP-1) - moving containers and loading parcels onto the roller conveyor $\left(100 \mathrm{~m}^{2}\right)$,
- Workplace 2 (WP-2) - removing parcels from chutes and loading them into containers $\left(1200 \mathrm{~m}^{2}\right)$,

- Workplace 3 (WP-3) - operating machines to sort small letters $\left(864 \mathrm{~m}^{2}\right)$.

The main activity of the organization is transport activity, which includes the services related to the delivery of letters and parcels in its area, as well as processing and transport to other processing centres.

The initial workplace (WP-1) consists of input conveyors, a vertical conveyor and output conveyors. Parcel shipments are loaded onto the roller conveyor. The roller conveyor is further automatically conveyed to the coding [16] and then to the input conveyor. After checking suitability, the parcel is loaded into the vertical elevator and transported to the level of the output conveyors. Using the output conveyor system, it is loaded onto the sorting truck platform (WP-2). The chain of trolleys with tilting platforms is one of the main parts of the sorting device. The route of the sorting device consists of supports and rails of a circular shape and serves as the travel path for a chain of trolleys. Sliding tracks transport sorted parcels from the chute surface to the chute table where the operator moves the shipment into prepared cages. In the letter sorting department (WP-3), the sorted letters from the cages of the sorting line are placed on the step belt conveyor which takes them to a binding machine. Consignments processed this way are moved to another workplace for further processing.

\section{RESULTS}

\section{A. Subjective Evaluation of the Risk Physical Factors Near to Conveyor System}

Subjective evaluation by the organization's employees took place from November 2017 to 
January 2018. The questionnaire survey contained 35 questions divided into five blocks. The aim of this research was to determine the severity of the influence of selected physical factors on the health and quality of working environment of employees. 125 copies of the questionnaire were distributed. The return rate was $96 \%$.

\section{Description of the research group}

The survey sample consisted of 120 employees, with $54(45.0 \%)$ men and $66(55.0 \%)$ women. In the age category of 18-27 years there were $12(10.0 \%)$ employees, in the age category of 28 37 years there were $24(20.0 \%)$. In the $38-47$ age category there were $48(40.0 \%)$ employees and $36(30.0 \%)$ employees were aged 48 or over.

A total of $54(45.0 \%)$ employees were overweight or had increased health risk from their high BMI, 16 (13.3\%) suffered from 1st degree obesity, 44 (36.7\%) employees were of optimal weight. A total of $76(63.3 \%)$ of staff have unfavourable BMI results. This fact is also currently considered as an emerging OHS risk, due to the aging of workforce. Another factor influencing the BMI level is night work and irregular alternation between day and night shifts, causing irregularities in eating habits, resulting in an inappropriate metabolic function. Up to $107(89.2 \%)$ of employees work night shifts and only $13(10.8 \%)$ work day shifts. The reason for this change is the increased flow of postal items mostly at night.

A total of 37 (30.8\%) of employees said they were working as an employee in shipping, 51 $(42.5 \%)$ in letter sorting and $32(26.7 \%)$ as a card worker. 25 (20.8\%) employees had been working at the given site for less than 5 years. As many as $113(94.2 \%)$ staff reported that they had undergone medical screening during the year with regard to the categorization of their work. 93 employees $(77.5 \%)$ had undergone audiometric examination. The employer affirmed that all employees are required to undergo a preventive medical check-up in order to identify and certify the health prerequisites for the performance of their specific work activity. An employee is required to undergo it once a year. Other data related to the satisfaction of the work environment, with the level of safety and health protection and their comparison with the past are presented in Tab. 1.

\section{Thermal-humidity microclimatic conditions at the workplace}

Only $21(17.5 \%)$ (or 23 , i.e. $19.2 \%$ ) employees are satisfied with the air temperature at the workplace during the warm (or cold) period of the year. Only $22(18.3 \%)$ (or 18 , i.e. $15.0 \%$ ) of employees are satisfied with the air humidity at the workplace during the warm (or cold) period

Table 1. Satisfaction of employees with the working environment

\begin{tabular}{|c|c|c|c|c|c|}
\hline Satisfaction & $\begin{array}{c}\text { Satisfaction } \\
\text { with the working } \\
\text { environment }\end{array}$ & $\begin{array}{c}\text { Level of health } \\
\text { and safety } \\
\text { protection }\end{array}$ & $\begin{array}{c}\text { Change } \\
\text { relative to } \\
\text { the past }\end{array}$ & $\begin{array}{c}\text { Satisfaction with the } \\
\text { working environment } \\
\text { relative to the past }\end{array}$ & $\begin{array}{c}\text { Level of health and } \\
\text { safety protection } \\
\text { relative to the past }\end{array}$ \\
\hline I'm very dissatisfied & $4(3.3 \%)$ & $2(1.7 \%)$ & No change & $21(17.5 \%)$ & $23(19.2 \%)$ \\
\hline I'm not satisfied & $22(18.3 \%)$ & $13(10.8 \%)$ & Improved & $53(44.2 \%)$ & $64(53.3 \%)$ \\
\hline It's suitable & $58(48.4 \%)$ & $56(46.7 \%)$ & Worsened & $18(15.0 \%)$ & $4(3.3 \%)$ \\
\hline I'm satisfied & $26(21.7 \%)$ & $39(32.5 \%)$ & Can't say & $28(23.3 \%)$ & $29(24.2 \%)$ \\
\hline I'm very satisfied & $10(8.3 \%)$ & $10(8.3 \%)$ & - & - & - \\
\hline
\end{tabular}

Table 2. Heat-humidity microclimatic conditions in the workplace $(n=120)$

\begin{tabular}{|c|c|c|c|c|c|c|}
\hline $\begin{array}{c}\text { Intensity of } \\
\text { expression }\end{array}$ & B1 & B2 & B3 & B4 & B5 & B6 \\
\hline Always & $21(17.5 \%)$ & $23(19.2 \%)$ & $22(18.3 \%)$ & $18(15.0 \%)$ & $14(11.7 \%)$ & $12(10.0 \%)$ \\
\hline Often & $28(23.4 \%)$ & $34(28.3 \%)$ & $25(20.8 \%)$ & $26(21.7 \%)$ & $32(26.7 \%)$ & $32(26.7 \%)$ \\
\hline Rarely & $67(55.8 \%)$ & $54(45.0 \%)$ & $67(55.8 \%)$ & $70(58.3 \%)$ & $69(57.5 \%)$ & $64(53.3 \%)$ \\
\hline Never & $4(3.3 \%)$ & $9(7.5 \%)$ & $6(5.0 \%)$ & $6(5.0 \%)$ & $5(4.2 \%)$ & $12(10.0 \%)$ \\
\hline
\end{tabular}

Explanation Notes: B1 - Satisfaction with air temperature during the warm season, B2 - Satisfaction with air temperature during the cold season, B3 - Satisfaction with humidity during the warm season, B4 - Satisfaction with humidity during the cold season, B5 - draught in the workplace, B6 - change of workplace with a higher temperature to a lower temperature workplace and vice versa. 
of the year. The air humidity at the workplace during the warm season is always satisfactory or often satisfactory for only $22(18.3 \%)$ or 25 $(20.8 \%)$ employees. Up to $67(55.7 \%)$ or 70 $(58.3 \%)$ of employees are rarely satisfied with air humidity during hot or cold weather. The reason for this assessment of air humidity by employees is the dissatisfaction with working conditions in WP-3. The machine processing of shipments, due to the rapid rotation in the machine, releases dust into the environment, resulting in the air drying in the workspace. At the workplace, draughts are always or often felt by $17(14.2 \%)$, and $32(26.7 \%)$ employees. Up to $64(53.3 \%)$ employees rarely change workplace with higher and subsequently lower temperatures and vice versa in their work place (Tab. 2).

Up to $64(53.3 \%)$ or $35(29.2 \%)$ employees rarely or never experience difficulties associated with overheating of the body during work. Up to $81(67.5 \%)$, or $17(14.2 \%)$ employees reported that they rarely or never have a cold. The feeling of cold limbs is rarely $58(48.3 \%)$ or never $38(31.7 \%)$ experienced by employees. The feeling of goose pimples is rarely experienced by 84 (70.0\%) employees. Up to 69 (57.5\%) employees report rare signs of weakness and malaise. Difficulties with breathing are never experienced by up to $62(51.7 \%)$ employees. Up to 81 (67.5\%) of staff reported rare headaches (Tab. 3).

\section{Noise in the workplace}

Up to $105(87.5 \%)$ employees reported that there are sources of noise directly in the workplace. The most frequent source of noise is the noise generated by machinery, equipment ( $92 \mathrm{em}-$ ployees). As a secondary source, 17 (14.2\%) employees referred to the noise generated by freight elevators and resulting from material transport. $11(9.2 \%)$ employees consider other sources of noise to be annoying (e.g. the railway). The building is located in the immediate vicinity of the railway line. $104(86.7 \%)$ of employees feel increased workplace noise, mostly at night. Up to 80 $(66.7 \%)$ employees state that their work does not allow the use of hearing protectors. Work procedures are designed in such a way that they prevent the use of this personal protective equipment.

A total of 55 (45.8\%) employees reported that they had never experienced physiological changes in the body (whistling, ringing in the ears). Total weakness and malaise during the working hours were rarely or never experienced by $76(63.3 \%)$, or $32(26.7 \%)$ employees. Nervousness, stress and depression were experienced during working hours, always by 9 (7.5\%), and often by 24 (20.0\%) employees. Concentration problems were rarely experienced by $71(59.2 \%)$, and never by 37 (30.8\%) employees. 53 (44.2\%) employees rarely and $53(44.2 \%)$ employees never have hearing

Table 3. Difficulties connected with microclimatic conditions in the workplace $(n=120)$

\begin{tabular}{|c|c|c|c|c|c|c|c|}
\hline $\begin{array}{l}\text { Intensity of } \\
\text { expression }\end{array}$ & PM1 & PM2 & PM3 & PM4 & PM5 & PM6 & PM7 \\
\hline Always & $3(2.5 \%)$ & $2(1.7 \%)$ & $12(10.0 \%)$ & $12(10.0 \%)$ & $4(3.3 \%)$ & $2(1.7 \%)$ & $2(1.7 \%)$ \\
\hline Often & $18(15.0 \%)$ & $20(16.7 \%)$ & $12(10.0 \%)$ & $24(20.0 \%)$ & $14(11.7 \%)$ & $3(2.5 \%)$ & $22(18.3 \%)$ \\
\hline Rarely & $64(53.3 \%)$ & $81(67.5 \%)$ & $58(48.3 \%)$ & $84(70.0 \%)$ & $69(57.5 \%)$ & $53(44.2 \%)$ & $81(67.5 \%)$ \\
\hline Never & $35(29.2 \%)$ & $17(14.2 \%)$ & $38(31.7 \%)$ & $0(0.0 \%)$ & $33(27.5 \%)$ & $62(51.7 \%)$ & $15(12.5 \%)$ \\
\hline
\end{tabular}

Explanations Notes: PM1 - overheating body, PM2 - cold, PM3 - feeling of cold limbs, PM4 - feeling of goose pimples, PM5 - weakness and malaises, PM6 - difficulties with breathing, PM7 - headache.

Table 4. Difficulties relating to noise in the workplace $(\mathrm{n}=120)$

\begin{tabular}{|c|c|c|c|c|c|c|c|}
\hline $\begin{array}{c}\text { Intensity of } \\
\text { expression }\end{array}$ & PH1 & PH2 & PH3 & PH4 & PH5 & PH6 & PH7 \\
\hline Always & $2(1.7 \%)$ & $2(1.7 \%)$ & $9(7.5 \%)$ & $3(2.5 \%)$ & $2(1.6 \%)$ & $1(0.8 \%)$ & $5(4.2 \%)$ \\
\hline Often & $3(2.5 \%)$ & $10(8.3 \%)$ & $24(20.0 \%)$ & $9(7.5 \%)$ & $12(10.0 \%)$ & $2(1.7 \%)$ & $12(10.0 \%)$ \\
\hline Rarely & $60(50.0 \%)$ & $76(63.3 \%)$ & $72(60.0 \%)$ & $71(59.2 \%)$ & $53(44.2 \%)$ & $37(30.8 \%)$ & $86(71.7 \%)$ \\
\hline Never & $55(45.8 \%)$ & $32(26.7 \%)$ & $15(12.5 \%)$ & $37(30.8 \%)$ & $53(44.2 \%)$ & $80(66.7 \%)$ & $17(14.2 \%)$ \\
\hline
\end{tabular}

Explanations Notes: PH1 - ringing or whistling in the ears, PH2 - overall weakness and malaise, PH3 - nervousness, stress, depression, PH4 - problems with concentration, PH5 - worsening hearing, PH6 - unspecified difficulties with breathing, PH7 - headache as a result of excessive noise. 
impairment. More than 80 (66.7\%) employees do not report more specific breathing difficulties. Headaches as a result of excessive noise are rarely experienced by 86 (71.7\%) employees (Tab. 4).

The first step to improving working conditions is to find out which work environment factors most affect employees. Despite the efforts of employers to ensure that working conditions are in line with legislation, the perception of the effect of factors on the employees is very diverse. Not all employees have the same working conditions. Also, not all the effects of these factors are considered by all employees to be equally satisfactory or unsuitable. To determine this subjective feeling, a questionnaire survey was selected. Employee responses provided diverse and extensive responses in areas where the questionnaire was targeted. The most important finding in this survey is that employees in the organization under review do not often experience the occurrence of the monitored health problems.

\section{B. Objective Evaluation of the Risk Physical Factors Near to Conveyor System}

When measuring the noise and the thermal-humidity microclimatic conditions, we proceeded according to the measurement methodology grounded in the valid legislation of the Slovak Republic.

\section{Results of measurement of thermal-humidity microclimatic conditions}

The thermal-humidity microclimate is an important physical factor in the environment which significantly affects working conditions in the workplace. When considering the thermal-humidity microclimate in a working environment, it is necessary to take into consideration the following aspects: 1.) Although it is possible to qualify and quantify each of the partial factors, the thermal-humidity microclimate is a complex of quantities and their interaction; 2.) the importance of exposure time, i.e. the time interval over which a person is exposed to thermal-humidity microclimate factors and the type of work activity; 3.) Different people's reactions to the same values of the same factor may vary; 4.) The effects of the thermal-humidity microclimate may be somewhat "mitigated" by the adaptation or acclimatization of the person [17].

In the survey, the following microclimatic conditions were measured at the monitored workplaces: dry air temperature, wet bulb temperature, relative humidity and air flow rate. These parameters were measured by the multifunctional Testo 435 instrument. The air temperature was simultaneously measured using a ball thermometer. The procedure for measurement of microclimatic conditions was based on the requirements set out in technical standard STN EN ISO 7933: 2004 [18] and Slovak Ministry of Health Decree no. 99/2016 [19]. Measurement uncertainty was determined with respect to the type of measurement by estimation $\left(\mathrm{t}_{\mathrm{a}} \pm 0.2^{\circ} \mathrm{C}, \mathrm{t}_{\mathrm{g}} \pm 0.5^{\circ} \mathrm{C}, \mathrm{rh} \pm 3.0 \%\right.$, $\left.\mathrm{v}_{\mathrm{a}} \pm\left(0.05+0.05 \mathrm{v}_{\mathrm{a}}\right)\right)$. Microclimate conditions in the workplace are satisfactory if measured values corrected for uncertainty of measurement are lower than the lowest acceptable values.

Measurements were performed at different measuring sites with a two-hour periodicity for 24 hours. The values of the individual parameters were measured after the devices had stabilized, at least 15-30 minutes later.

Measurement took place during the cold period of the year. External temperatures ranged from $0^{\circ} \mathrm{C}$ to $+4^{\circ} \mathrm{C}$. Average daily values: Air Flow Rate $4.25 \mathrm{~m} . \mathrm{s}^{-1}$, Relative Air Humidity 78.7\%, and Atmospheric Pressure $991 \mathrm{hPa}$.

In the following table, we give average values for individual workplaces where specific measurement locations were determined.

Because of the very frequent change of employees during work changes due to the diversity of technological processes and procedures during the work shift, the exposure to the thermalhumidity microclimatic factors for employees in individual jobs must be taken into account (Tab. 6 ). Values measured in all monitored workplaces are stated in Figure 2.

Table 5. Average values over 24-hours

\begin{tabular}{|c|c|c|c|c|c|c|c|}
\hline \multirow{2}{*}{$\begin{array}{c}\text { Measuring } \\
\text { point }\end{array}$} & \multicolumn{7}{|c|}{ Calculated average value } \\
\cline { 2 - 9 } & $\mathrm{t}_{\mathrm{a}}\left[{ }^{\circ} \mathrm{C}\right]$ & $\mathrm{v}_{\mathrm{a}}\left[\mathrm{m} . \mathrm{s}-{ }^{-1}\right]$ & $\mathrm{rh}[\%]$ & $\mathrm{t}_{\mathrm{g} 1}\left[{ }^{\circ} \mathrm{C}\right]$ & $\mathrm{t}_{\mathrm{g} 2}\left[{ }^{\circ} \mathrm{C}\right]$ & $\mathrm{t}_{\mathrm{g}}\left[{ }^{\circ} \mathrm{C}\right]$ & $\mathrm{t}_{\mathrm{g}}\left[{ }^{\circ} \mathrm{C}\right]$ \\
\hline WP-1 & 16.3 & 0.17 & 31.8 & 16.0 & 16.2 & 16.8 & 16.3 \\
\hline WP-2 & 18.2 & 0.04 & 30.4 & 17.9 & 18.3 & 18.8 & 18.3 \\
\hline WP-3 & 22.7 & 0.03 & 23.7 & 20.7 & 21.6 & 21.8 & 21.4 \\
\hline
\end{tabular}


Table 6. Exposure to THM for different professions

\begin{tabular}{|c|c|c|c|c|c|c|}
\hline Profession & Measuring point & Exposure [min.] & $\left.\mathbf{t}_{\mathrm{a}}{ }^{\circ} \mathbf{C}\right]$ & $\mathbf{v}_{\mathbf{a}}\left[\mathbf{m . s}^{-1}\right]$ & $\mathbf{r h}[\%]$ & $\mathbf{t}_{\mathbf{g}}\left[{ }^{\circ} \mathbf{C}\right]$ \\
\hline Shift leader $^{\mathrm{a})}$ & - & - & - & - & - & - \\
\hline \multirow{2}{*}{ Foreman ${ }^{\mathrm{b})}$} & WP-2 & 60 & 16.3 & 0.17 & 31.8 & 18.3 \\
\hline \multirow{2}{*}{ Sorter 1 } & WP-1 & 70 & 16.3 & 0.17 & 31.8 & 16.3 \\
\cline { 2 - 7 } & WP-2 & 110 & 18.1 & 0.04 & 30.4 & 18.3 \\
\hline \multirow{2}{*}{ Sorter 2 } & WP-1 & 75 & 16.3 & 0.17 & 31.8 & 16.3 \\
\cline { 2 - 7 } & WP-2 & 120 & 18.2 & 0.04 & 30.4 & 18.3 \\
\hline Post transport worker & WP-3 & 445 & 22.7 & 0,03 & 23.7 & 21.4 \\
\hline
\end{tabular}

Explanations Notes: ${ }^{\text {a) }}$ - performs supervisory and management activity in the given department and moves

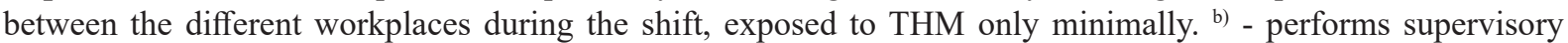
and management activity in the given department and moves between the different workplaces during the shift, exposed to THM only at WP-2.

\section{Results of measuring noise in the workplace}

The indirect measurement method was chosen to measure noise. A Norsonic sound analyzer was used to measure noise exposure. Evaluation of the noise measurement results consisted of comparison of the measured values with the required values, which are specified, in the relevant legislative regulation (Act No. 115/2006 [20], technical standard (STN EN ISO 9612:2010) [21] and Directive (Council Directive 2003/10/EC) [22]. Due to the measurement method used, the measuring instrument, the measuring conditions and the experience of the measurers, the measurement was subject to a measurement error of $\mathrm{U}= \pm 2.1 \mathrm{~dB}$.
The measurement site, duration of measurement and sample selection were chosen so that the result represented and characterized the exposure of an employee. The location of the microphone was at least $100 \mathrm{~cm}$ away from the employee's ear. The sounder was placed on a tripod at a height of $150 \mathrm{~cm}$ above the floor level. In the following table (Tab. 7), the specific occupational noise exposure values of employees are calculated for individual professions in relation to the work performed. The measurement was performed during the normal work activity of employees. The durations of exposures are calculated in accordance with STN ISO 9612:2010. Measured values for all workplaces are given in Fig 3.

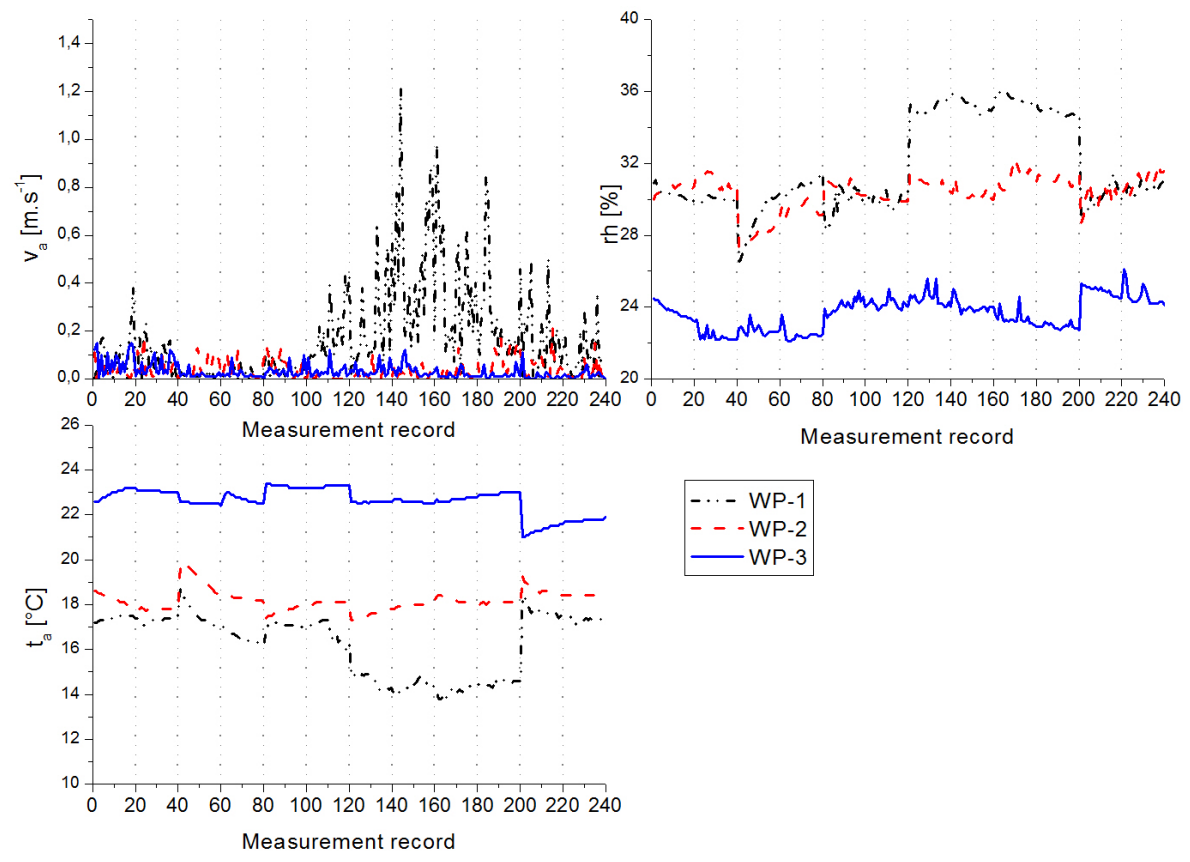

Fig. 2. Values of THM parameters measured 
Table 7. Exposure to noise for individual jobs

\begin{tabular}{|c|c|c|c|c|c|}
\hline Profession & $\begin{array}{c}\text { Place of } \\
\text { measurement }\end{array}$ & $\begin{array}{c}\text { Equivalent level } A \text { of } \\
\text { acoustic pressure } \\
L_{\text {Aeq, } \mathrm{T}}[\mathrm{dB}] \\
\end{array}$ & $\begin{array}{l}\text { Duration of } \\
\text { exposure } \\
T_{e} \text { [hour.] }\end{array}$ & $\begin{array}{l}\text { Standardized level of exposure } \\
\text { to noise during a working shift } \\
\qquad \mathrm{L}_{\mathrm{AEX}, \mathrm{gh}}[\mathrm{dB}]\end{array}$ & $\begin{array}{c}\text { Peak level C of } \\
\text { acoustic pressure } \\
\mathrm{L}_{\mathrm{Cpk}, \mathrm{T}}[\mathrm{dB}] \\
\end{array}$ \\
\hline \multirow{2}{*}{ Sorter 1} & WP-1 & 74.7 & 1.2 & \multirow{2}{*}{71.4} & 109.7 \\
\hline & WP-2 & 73.3 & 1.8 & & 109.1 \\
\hline \multirow{2}{*}{ Sorter 2} & WP-1 & 74.7 & 1.3 & \multirow{2}{*}{71.6} & 109.7 \\
\hline & WP-2 & 73,3 & 2.0 & & 109.1 \\
\hline $\begin{array}{l}\text { Post transport } \\
\text { worker }\end{array}$ & WP-3 & 77.5 & 7.4 & 77.5 & 112.1 \\
\hline
\end{tabular}
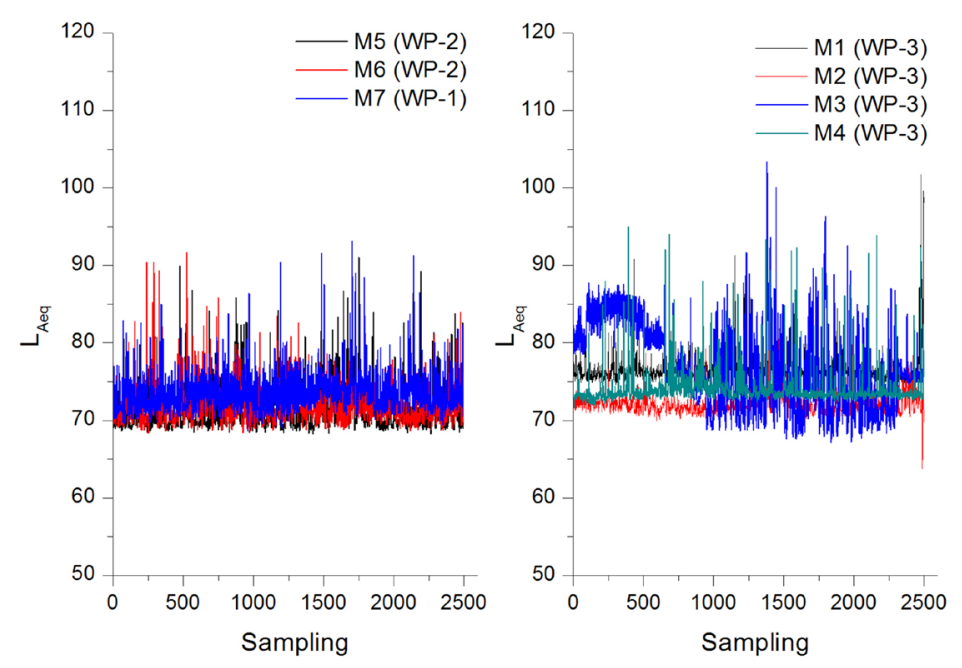

Explanations Notes: one sample $=0,125 \mathrm{~s}$.

Fig. 3. Measured value of noise

\section{DISCUSSION AND CONCLUSION}

In this paper approaches and methods were used for evaluating the subjective and objective evaluation of selected physical factors (noise, thermal-humidity microclimates) in the working environment of an organization for processing parcels and letters at three workplaces. The effect of these factors has a direct impact on the quality of the working environment and thus also on the employee. Employers are primarily driven by the results obtained from professional measurements at specified times and in changing workflows and technologies. A secondary stimulus to solving the quality of the working environment is the evaluation of working conditions by the department heads in cooperation with employers' representatives. Such a secondary output is, in the hot or cold season, for staff to take breaks beyond those required by the labour code for cooling, refreshment, or warming.

In order to evaluate the subjective response of the employees $(n=120)$ to the selected physical factors in the work environment, a questionnaire was created which the employees completed directly in the workplace. The aim of this research was to determine the severity of the influence of selected physical factors on the health and quality of the working environment of the employees. The most important findings from the point of view of subjective assessment by employees were that they did not experience frequent health problems, which we can consider to be a very positive finding. Regarding satisfaction with the working environment of employees, 58 (48.3\%) said they were satisfactory. Only $26(21.2 \%) \mathrm{em}-$ ployees said they were dissatisfied or very dissatisfied with the conditions at their workplace. As many as $53(44.2 \%)$ said the conditions in their workplace had improved compared to the past. The employer has confirmed that the employer is constantly trying to improve the conditions of the working environment for its employees. In evaluating the microclimatic conditions, the employees expressed dissatisfaction with the air humidity at 
workplace WP-3, where air dries due to the rapid rotation of letters. 104 (86.7\%) of employees experience an increase in noise levels at night. As the employer has explained to us, the highest frequency of processing of letters and parcels is during the night shift. In-service personnel do not use personal hearing protectors. This measure is not implemented because previous noise measurements have not confirmed the need to use PPE related to hearing protection. Employees have confirmed to us ( 80 employees, $66.7 \%$ ) that their work does not even enable them to be used. The employer has confirmed that workflows are designed in such a way that the use of these devices is not possible. From a health point of view, employees reported that they rarely encounter all the monitored health problems (Tab. 4).

From the results of the subjective response of the employees, it is possible to precisely determine the areas where improvement or correction is needed.

The question of the extent to which the physical factors of work and the working environment pose a risk to the health of the employee or the extent to which the measures are effective is assisted by the values of the variables recorded. Their compliance or excess indicates not only the degree of risk but also the level of health protection of employees. Within the Slovak Republic, the basis for assessing the fulfilment of these requirements is the results of direct or indirect measurement and comparison with the permissible values determining the quantities as stipulated in legislation and technical standards.

From the measurement results in the monitored jobs (or professions), it is clear that the values of microclimatic conditions in most of the workplaces comply with the current legislative requirements, with the exception of relative air humidity, which ranged from $(23.73 \pm 3 \%)$ to $(31.79 \pm 3 \%)$. WP-2 $(30.39 \pm 3 \%)$ and WP-3 $(23.73 \pm 3 \%)$ were not at the time of measurement in accordance with the permissible values of relative humidity in accordance with Decree of the Ministry of Health of the SR no. 99/2016. This result corresponds to the questionnaire survey where 67 (55.83\%), and 70 (58.33\%) employees are rarely satisfied with air humidity during hot and cold weather respectively. In order to create favourable microclimatic conditions in these workplaces, the installation of air conditioning units, which have a function of heating, cooling, air purification as well as the function of maintaining the optimum air humidity, took place.
Minimizing workplace noise is one of the basic tasks for maintaining safety at work, both in terms of health (especially of the hearing organ) and comfort of work [ $23 \div 25]$. According to EN ISO 11204 [26], the parcel shipment sorting equipment placed in WP-1 and WP-2 under the conditions of a running sorting device without parcel handling is $75 \mathrm{~dB}$ for the entry workstation (WP-1) and $65 \mathrm{~dB}$ for the sorting workplace (WP-2). Noise in the workplace was assessed for each job, namely for a sorting worker and postal transport worker. It is clear from the measurement results of the monitored job positions that the noise load values of all job positions comply with current legal requirements.

The results of this study show that the employer creates a working environment for employees that, in the long run, should not cause permanent health complications for employees employed in the positions considered.

\section{Acknowledgements}

This paper was written in the framework of the work on the projects KEGA 041TUKE4/2018 (50\%). The Slovak Research and Development Agency supported this work under the contract No. APVV- 0432-12 (50\%).

\section{REFERENCES}

1. Honus S., Bocko P., Bouda T., Ristovic I., Vulic, M. The effect of the number of conveyor belt carrying idlers on the failure of an impact place: A failure analysis. Eng. Failure. Analys., July (77), 2017, 93-101.

2. Molnár V., Fedorko G., Stehlíková B., Tomašková M., Hulínová Z. Analysis of asymmetrical effect of tension forces in conveyor belt on the idler roll contact forces in the idler housing. Meas J Int Meas Confed., 52(1), 2014, 22-32.

3. Jachowicz T., Sikora J., Dulebova L.: Investigating effects of prodegradant content on selected properties of polymer composite materials. Environ Eng Manag J, 12(6), 2017, 2879-2886.

4. Mikusova N., Millo S. Modelling conveyor belt passage with a driving drum using finite element methods. Adv Sci Technol Res J., 11(4), 2017, 239-246.

5. Debski H., Teter A., Kubiak T., Samborski S. Local buckling, post-buckling and collapse of thinwalled channel section composite columns subjected to quasi-static compression. Compos Struct., 136, 2016, 593-601.

6. Ševčíková L. Hygiene - Environmental Medicine. Comenius University Publisher, editor. Bratislava, 2011, 330 p. 
7. Dianat I., Vahedi A., Dehnavi S. Association between objective and subjective assessments of environmental ergonomic factors in manufacturing plants. Int J Ind Ergon., 54, 2016, 26-31.

8. Gavhed D., Toomingas A. Observed physical working conditions in a sample of call centres in Sweden and their relations to directives, recommendations and operators' comfort and symptoms. Int J Ind Ergon., 37, 2007, 790-800.

9. Seňová A., Slaninová P., Weiss E. Evaluation of risk by point method for selected carrer in mining industry. Acta Montan Slovaca., 13(2), 2008, 278-84.

10. Hnilica R. Synergy effect of risk factors in working environment and methods their assessment. Acta Fac Tech., 17(2), 2012, 25-34.

11. Hrušková M., Buchancová J., Strýčková M., Zibolenová J., Zelník Š., Hudečková H. Sledovanie a hodnotenie zdravotného stavu zamestnancov vo vybraných prevádzkach automobilového priemyslu. Prac Lek., 67(3-4), 2015, 86-91.

12. Hnilica R., Jankovský M., Dado M., Messingerová V., Schwarz M., Veverková D. Use of the analytic hierarchy process for complex assessment of the work environment. Qual Quant., 51(1), 2017, 93-101.

13. Kapustová M. Aplikácia matematických metód pri ekologizácii pracovného prostredia $\mathrm{v}$ strojárskych prevádzkach. Mater Sci Technol., (2), 2004, 1-5.

14. Tolvanen K. Exposure to bioaerosols and noise at a Finnish dry waste treatment plant. Waste Manag Res., 22(5), 2004, 346-57.

15. Lumnitzer E., Piňosová M., Andrejiová M., Hricová B. Methodology of complex health risk assessment in industry 2. 1. Zręcin: MUSKA sp. z o.o., 2013, 326 p.

16. Ivaniga P., Ivaniga T. Comparison of DPSK and RZDPSK modulations in optical channel with speed of 10 Gbps. J Inf Organ Sci., 41(2), 2017, 185-96.
17. Slamková E., Dulina L., Tabaková M. Ergonómia v priemysle. 1. GEORG, 2010, $262 \mathrm{p}$.

18. STN EN ISO 7933:2004 Ergonomics of the thermal environment - Analytical determination and interpretation of heat stress using calculation of the predicted heat strain.

19. Vyhláška Ministerstva zdravotníctva Slovenskej republiky č. 99/2016 Z. z. o podrobnostiach o ochrane zdravia pred zát’azou teplom a chladom pri práci.

20. Nariadenie vlády Slovenskej republiky č. 115/2006 Z. z. o minimálnych zdravotných a bezpečnostných požiadavkách na ochranu zamestnancov pred rizikami súvisiacimi s expozíciou hluku.

21. STN EN ISO 9612:2010 Acoustics. Determination of occupational noise exposure. Engineering method.

22. Smernica Európskeho parlamentu a Rady 2003/10/ ES o minimálnych zdravotných a bezpečnostných požiadavkách, pokial' ide o vystavenie pracovníkov rizikám vyplývajúcim z fyzikálnych faktorov (hluk).

23. Mika D., Józwik J. Normative measurements of noise at $\mathrm{CNC}$ machines work station. Adv Sci Technol Res J., 10(30), 2016, 138-43.

24. Moravec M., Liptai P., Dzuro T., Badida M. Design and Effectiveness Verification of Sound Reduction Measures in Production Hall. Adv Sci Technol Res J.,11(4), 2017, 220-224.

25. Lilic N., Cvjetic A., Milisavljevic V., Pantelic U., Kolonja L. Environmental Noise Management in the Area of Opencast Mines. Tehnika, 17(1), 2017, 47-52.

26. ISO 11204:2010 Acoustics - Noise emitted by machinery and equipment - Determination of emission sound pressure levels at a work station and at other specified positions applying accurate environmental corrections. 